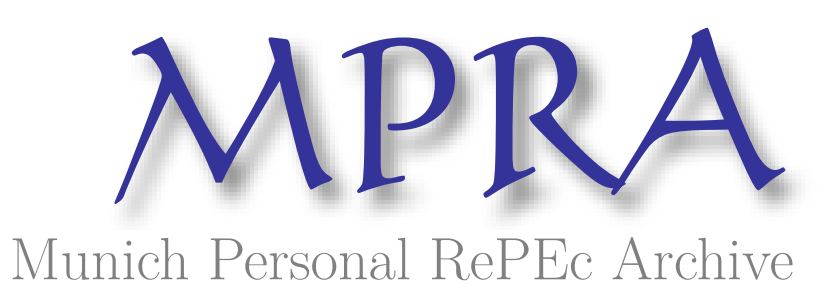

\title{
Heaven knows I'm miserable now: overeducation and reduced life satisfaction
}

Piper, Alan T.

Staffordshire University, UK, Universität Flensburg

July 2012

Online at https://mpra.ub.uni-muenchen.de/43259/

MPRA Paper No. 43259, posted 14 Dec 2012 05:23 UTC 


\title{
Heaven Knows I'm Miserable Now: Overeducation and Reduced Life Satisfaction.
}

July 2012

\author{
Alan Piper \\ Staffordshire University Business School \\ Leek Road, Stoke-on-Trent, Staffordshire, ST4 2DF \\ 01782295902 \\ A.T.Piper@staffs.ac.uk
}

(updated email: alan.piper@uni.flensburg.de) 


\section{Heaven Knows I'm Miserable Now: Overeducation and Reduced Life Satisfaction.}

This study is an investigation into relative overeducation and life satisfaction using British longitudinal data. The focus is on young people rather than the whole of the life cycle, an arguably more homogenous group. Such a focus means that the overeducation variable does not simply capture the increased participation in Higher Education of the young. The hypothesis is that there is a negative relationship between being overeducated and life satisfaction. Overeducation is measured using the realised matches approach, a statistical measurement comparing an individual's years of schooling with the average for one of two employment based reference groups. Using dynamic panel analysis, to account for the presence of serial correlation, such an association is found: the relatively overeducated seem to be relatively less happy.

Keywords: Life Satisfaction, Happiness, Overeducation, Dynamic Panel Analysis, BHPS.

Acknowledgements: For comments on earlier drafts, helpful discussions and advice the author is grateful to Nick Adnett, Andrew Clark and Geoff Pugh as well as seminar participants at Staffordshire University and Universität Flensburg. Thanks 
also to participants at the 2012 IWAEE event in Catanzaro, Italy, who also made valuable suggestions. The usual disclaimer applies. 


\section{Heaven Knows I'm Miserable Now: Overeducation and Reduced Life Satisfaction.}

\section{Introduction}

Within economics, an investigation into overeducation and life satisfaction has (to my knowledge) never been undertaken before. The broad hypothesis is that the relatively overeducated may experience less average life satisfaction (ceteris paribus). In this section, the theoretical discussion, suggests pathways through which there might be an association between overeducation and (un)happiness. One of these is through raised expectations being unmet; another is through the comparisons being made by individuals with others in the same position in terms of employment who have invested less in their education. There is an extensive overeducation literature, where measurement issues have been deemed to be important and these issues are also analysed in this section below. Following this, in the same section, there is a brief review of the overeducation and job satisfaction literature. There are some happiness and education studies which hint at an association between them via overeducation (though not explicitly) and these are also discussed. The literature review, theoretical foundations and hypothesis are all discussed in section 2 . The specific methodological issues for the empirical investigation are discussed in section 3. The results and concluding remarks follow, in sections 4 and 5 respectively.

Before those more detailed sections, here a brief argument is made for a potential negative relationship between life satisfaction and overeducation, arising through 
unmet aspirations and comparisons with other individuals who are not overeducated. Relative or comparison effects have been repeatedly argued to be and demonstrated as important both within economics and particularly 'the economics of happiness' literature. (For example, Veblen 1890, Dusenberry 1948, Frank 1985, and Clark et al. 2008, all provide either arguments or evidence or both for the importance of relative concerns.) The relatively overeducated are doing the same (or a similar) job as others but have invested more in education. This comparison is one potential pathway through which being relatively overeducated may depress life satisfaction. A relatively overeducated individual may make another comparison with a similar outcome: a comparison with the past (or their current situation and their expectations formed in the past). An individual may have invested in more education, only to find that his or her employment situation has not improved much (or at all). As the education has had little or no labour market impact, the individual may wonder whether it was worth it and be less satisfied because of this.

Little theoretical guidance comes from other disciplines. From psychology and sociology there are, currently, few studies that look at the relationship between overeducation and mental well-being. Notable examples are Kasl (1974) and Coburn (1975), which both found adverse effects on mental well-being amongst overeducated individuals via an achievement and aspiration mismatch, as suggested above. Interestingly, Coburn (1975) also found that if overeducation is self-perceived, rather than objectively measured, the adverse effects on mental well-being are more significant, a finding considered further in the subsequent literature review. Within psychology, there are contributions to the emerging literature that links non-cognitive skills with labour market outcomes, for example Blázquez Cuesta and Budría (2011). 
The relationship between personality and the specific labour market outcome of overeducation is analysed by Blázquez Cuesta and Budría although that study whilst interesting seems to have a fundamental flaw (discussed in the literature review), and other research is currently underway linking personality types and personality changes to happiness (e.g. Boyce et al. 2012). A link between personality and happiness may provide more theoretical underpinnings for an investigation into the relationship between overeducation and happiness, though the work has not been done yet and is not undertaken here since the reason why overeducation may depress life satisfaction is not something that is directly investigated. This is something that is very difficult to undertake with most available data sets, including the British Household Panel Survey (BHPS). Instead the subsequent analysis attempts to empirically establish whether there is such an association. If found this would represent the first evidence for such a relationship within the economics literature (to my knowledge). There are challenging methodological issues involved, and these are discussed both within the literature review of section 2, and the subsequent methodological discussion of section 3 .

\section{Theoretical underpinnings and literature review}

This critical review cannot discuss previous studies of the relationship between overeducation and life satisfaction because none exist. Although there are, within the happiness and education literature some studies that hint at an association via overeducation. Some of these studies are briefly mentioned here, complementing the overeducation discussion. Also there is an extensive overeducation literature (often linked to job satisfaction), which is critically reviewed. The literature defines 
overeducation as 'having more education than is required for one's job' (Rubb, 2003) and various explanations for being overeducated include individuals overcompensating for their lack of other ability or experience, or as part of a career plan (Sicherman 1991; Groot 1993). Similarly, overeducation could also result from having no career plan. There is some evidence to suggest that how overeducation is measured has significant consequences for its incidence and any subsequent empirical results. These studies are discussed here with their implications for the subsequent analysis.

The increase of participation in HE in the UK, discussed in section 6.1.1, raises the possibility of an increase in the incidence of overeducation. Belfield (2000) makes a similar comment about countries other than the UK, demonstrating that such concerns are shared elsewhere:

With rapid recent expansion of participation in higher education in most Western economies, there are concerns that some graduates may find a degree to be a poor investment (although these concerns do appear to be perennial, Lange 1998). Some new graduates may find work for which they are overeducated or at which they are under utilised (Belfield 2000, p.35).

Groot and Massen van den Brink (2000) in a meta-analysis of both the incidence of, and the economic returns to, overeducation, offer OECD statistics to support their claim that 'one of the most remarkable social developments of past decades in all western countries has been the increase in the educational level of the population' (p.149). If this increase in the supply of higher educated labour is not matched with the demand for highly-educated labour, widespread overeducation is a possibility. The meta-analysis of Groot and Massen van den Brink (2000) discusses several different ways of measuring overeducation. Some are subjective, where an individual is asked about the skills/education required to do the job; and some are objective where job 
requirements are investigated, or a comparison is made between an individual's education and that of a reference group (often based on a broad occupational category). A later useful summary is provided by Verhaest and Omey (2006), where two subjective and two objective methods are discussed. The two subjective methods are direct self- assessment and indirect self-assessment: the former is, in short, simply asking an individual if he/she is overeducated for the job he/she is doing; the latter is to ask an individual about the appropriate education level for their job and then make a comparison with the individual's actual education. The objective methods are job analysis and realised matches: job analysis bases the education level required on an occupational classification made by job analysts; realised matches involves comparing the individual's level of education with the average or modal level of education of workers in each occupation.

Each of these methods has limitations. These limitations are discussed in Groot and Massen van den Brink's (2000) meta-analysis, the meta analysis of Rubb (2003) as well as Verhaest and Omey (2006). In short, the very subjectivity of the responses regarding an individual's opinion about his/her own job (what skills are necessary? what education does the job require?) is problematic for quantitative analysis: individuals may be influenced by adapted expectations, formal requirements for new hires (which may overestimate qualifications necessary given increasing supply of qualified labour), the education that they themselves have (among other possible influences). Conversely, the job analysis objective method classification cannot take into account the likely heterogeneity of jobs within occupations. A similar criticism can be levelled at the realised matches approach (the approach that is used later in this study, and thus critiqued further below). The choice made regarding the measurement 
of overeducation is likely to be important. Meta analyses (Groot and Massen van den Brink 2000; Rubb 2003; Kucel 2011) find significant differences in the both the incidence of overeducation, and, where also investigated, the subsequent results (e.g. returns to education, job satisfaction). The Kucel study widens the focus to sociology, psychology and demography and supports the finding of differences of overeducation incidence by measurement method in earlier work. This is based on studies from six different countries, including the UK. A counter claim is that these substantial differences could result from sample heterogeneity and not from the choice of measurement itself. As Verhaest and Omey (2006) assert 'no uniform way of measuring overeducation exists. The main reason for this lack of uniform measurement is the dependency of empirical researchers on the availability of relevant data to measure overeducation' (p.419). They themselves make use of Belgian SONAR data which provides information about the four methods of measuring overeducation mentioned above. The differences in the incidence of overeducation are striking: approximately half of individuals are overeducated based on the job analysis method, the subjective methods suggest that between approximately 32 and $43 \%$ of individuals are overeducated, and the realised matches method results in the lowest incidence of overeducation in the sample, at nearly $14 \%$. Also the 'correlations [of the different measures] are fairly low for indicators that have to measure the same variable' (Verhaest and Omey 2006, p.425-426). Certainly, measurement is likely to matter for the happiness association investigated here, where the 'realised matches' method used gives low estimates (when compared to other measures) of the incidence of overeducation, 
Due to pragmatic concerns of data availability, the analysis presented in the later sections of this investigation will use the objective method (realised matches) as used by Groot (1996). Additional studies that have used this method are Verdugo and Verdugo (1989) and Kiker et al. (1997). Groot (1996) uses the first wave of the BHPS, a subsection of the data that is utilised in this thesis, to investigate the extent of overeducation in the UK. In short, a comparison is made between an individual's education level and the average education level of individuals in the same occupation category. Individuals are then classed as overeducated if their level of education is more than one standard deviation above the average. A more critical assessment of this approach appears in the methodology discussion below (section 3). Groot (1996), using the one standard deviation definition, finds overeducation within this wave of the BHPS (i.e. 1991) to be at $11 \%$ and undereducation to be $9 \%$, with males being less well 'skills matched' than females.

Further evidence for overeducation for UK graduates comes from Dolton and Vignoles (1997) who find that 38\% of graduates are overeducated for their first job, a figure that falls to $30 \%$ six years after graduation. Data from the 1995 Labour Force Survey puts graduate overeducation at between 27\%-38\% (Alpin et al. 1998) and a survey from 1996 puts the figure at 40\% (Battu., et al 1999). This suggests that overeducation, for graduates, has, for some time, been a sizeable issue. Belfield (2000, p.38) asserts that 'although there has been a large expansion in the numbers of graduates in the UK over the last ten years, there is no clear evidence that overeducation has increased.' This is not a universal judgement. Groot's meta-analysis of the same year makes contradictory claims regarding how the incidence overeducation 
has changed over time, and section 3 below provides evidence of increasing overeducation since 1991 with British (BHPS) data.

The main focus here is on the happiness of the relatively overeducated; however, the rates of return to education and overeducation, not especially considered here, are potentially important channels and income must be controlled for. A recent metaanalysis, Leuven and Oosterbeek (2011), suggests a rate of return for a year of required (or matched) schooling of about $9 \%$, whereas the return to a year of overeducation is about $4.5 \%$. Some studies, largely from within psychology, do not control for income and thus present an unconditional correlation for the impact of education (and overeducation) on non-monetary outcomes. An example of this is Cassidy and Wright (2008), who look at graduate employment status and its association with psychological well-being (among other factors). They use different measures of health, including the GHQ-12 scores, popular as a proxy for happiness in the economic literature. They use a small sample, based on a questionnaire administered at two points in time, and results indicate that graduate underemployment is detrimental to psychological health. Here underemployment is defined by the individuals responding to the survey as being in a 'stop-gap' job, perhaps similar to a subjective assessment of overeducation. However, it should be noted, that this study does not take into account any impact of low(er) income (from unemployment and underemployment) on well-being, which may have a modifying effect on the unhappiness of both graduate employment statuses - unemployment and underemployment - studied here. Are underemployed individuals relatively unhappy because of a lower income or is it because of the nature of their employment? The Cassidy and Wright study cannot make this distinction. The study is also limited by its 
small sample size (less than 250 individuals), and its focus on individuals who were students at just one UK university.

Another interesting study is Blázquez Cuesta and Budría (2011), which investigates the impact of personality traits on transitions into and out of jobs for which individuals were overeducated. They employ the realised matches method of measuring overeducation based on occupation category and find, using the German Socio-Economic Panel between 2000 and 2008, an 86-89\% state dependence to overeducation, which means that $86-89 \%$ of individuals in the sample overeducated in one year, are overeducated in the subsequent year. Given that the average age of the respondents is 41.5 , it is unlikely that years of schooling will be changing for many of these individuals: what they are really measuring is transitions into and out of occupational categories. The authors find the persistence rate of overeducation to be 'remarkably large... [and that] only two percent of those who were not overeducated in one particular year are overeducated in the following year' (Blázquez Cuesta and Budría 2011, p.11). This seems to have little to do with overeducation per se, and more to do with people changing jobs and entering different occupations. It appears that not many people change jobs. Given the increase in participation in higher education in Western Nations like Germany (established in section 6.1), it is likely that their overeducation dummy is capturing to a large extent younger people. Our study, with its focus on the twenties does not face this problem of overeducation capturing the cohort change of increasing qualifications amongst the young (see section 6.1). Whether the dummy simply captures this effect in the Blázquez Cuesta and Budría study is unclear because little information is given about the breakdown of the overeducated in this study. Also, little information is given regarding the 
occupational categories and this is a major omission since the study is really about the transitions into different occupations (however they are measured), rather than transitions into and out of overeducation. Whether the persistence figures are 'remarkably large' or not depends on a comparison with typical rates of individuals changing their occupation category. It is not a claim that can be made without this information.

Fleming and Kerr (2005) use Australian data to investigate the relationship between overeducation and job satisfaction. They find some evidence that being overeducated in the labour market can lead to reduced job satisfaction (and lower productivity), although the implications for 'whole of life' satisfaction remain untested (until now). Belfield (2000), in a survey, argues similarly, stating that 'matched' (i.e. neither over nor undereducated) workers report significantly higher levels of job satisfaction than unmatched workers. Studies such as Veenhoven (1996) and Khattab and Fenton (2009), find evidence that, in some cases, the highly educated are less satisfied with life than individuals who are considered to have a medium level of education. The authors speculated that this negative association may have been due to a lack of available jobs at that level of education, and that perhaps unhappiness is also due to the aspirations or expectations-increasing nature of education (which are relatively unmet by the overeducated). Thus, being overeducated may have negative consequences for well-being, after controlling for income (and other standard controls). This presents the central hypothesis of the analysis:

\section{H1: Being overeducated is correlated with a lower level of happiness (ceteris paribus]}


The next section discusses the data used and the reasons for the particular econometric approach utilised.

\section{Data discussion and methodology}

The hypothesis of lower life satisfaction for the relatively overeducated is investigated via a modification of the happiness function. Here a dummy variable for the relatively overeducated is included. Establishing the incidence of overeducation, in the first instance, follows the method of Groot (1996), the realised matches method: a comparison is made between an individual's education level and the average education level of their job, as demonstrated by one of nine broad occupational classifications. In addition to this, a refinement is made where the broad occupational category is combined with a broad industry indicator to create eighty-one smaller reference groups. A further dummy variable was created which measure relative overeducation by both occupation and gender combined: on the basis that males may compare themselves primarily with other males and females with other females. In practice, the results from this addition are qualitatively the same as those for the dummies mentioned above, and as such are not discussed further. In each case, an individual is classed as overeducated if their level of education is more than one standard deviation above the average years of education for their peers (those in the twenties age range) in the same occupational group (or occupation-industry group for the alternative measurement). ${ }^{1}$ This 'realised matches' approach gives, as the literature review above explains, the lowest incidence of overeducation of the various

\footnotetext{
${ }^{1}$ The actual amount of years is quite varied dependent upon the reference group.
} 
measures, thus being a more demanding criterion for assessing overeducation. Here this measurement is chosen for pragmatic reasons of data availability and is not without its problems which are also discussed in the literature review. As Sloane et al. (1999) note, overeducation as measured by Groot does not account for the heterogeneity of jobs in the Standard Occupational Classifications, and the quality of education is difficult to take into consideration. Also education and overeducation, when measured by years of schooling, does not take into account the different levels of attainment that individuals have. The inclusion of an industry classification mitigates this first criticism somewhat, but not wholly so: the remaining categories will still contain heterogeneity in terms of the jobs individuals do. Also Groot's analysis considered all ages as the comparator group so his overeducation variable may well have been picking up cohort effects: younger individuals have, on average, more years of education. Restricting the sample to the twenties age range means that the analysis here is relatively free from this objection. The changing pattern of participation of individuals within education over time is well-known, with a significantly higher percentage of younger people having higher qualifications than older individuals. With current large data sets, like the BHPS, it is impossible to consider the potentially varying quality of education. Also, it is important to note that the two measures of overeducation (occupation, and occupation combined with industry) here do not cover the same years due to data availability. The industry data is incomplete in the BHPS, and this affects waves 16 and 17, reducing the amount of observations we can use.

The following table demonstrates the incidence of overeducation, i.e. individuals in their twenties who have more than one standard deviation more of education 
(captured by years of schooling) than the mean for their reference group. The two reference groups are individuals in the same broad occupational category (1), and the combination of the occupation and industry groups (2), both of which are discussed above. The percentages in the columns for these groups relate to the twenties age range. This tweak for the second reference group uses the 9 broad occupational groups of Groot (1996) and combines them with 9 broad industry categories, forming 81 different groups. This somewhat reduces the effects of job heterogeneity. The reference group for each individual is now much smaller, and this is reflected in the table below with lower percentages of individuals being classed as overeducated. This is because the size of the group, in some cases, is quite small and no individual is classed as overeducated when measured by the standard deviation criteria.

\section{[TABLE ONE ABOUT HERE]}

The pattern here of increasing incidence of overeducation over time is consistent with increasing participation in higher education of young people, and an outcome we would expect to see in a nationally representative dataset like the BHPS. Interesting to note, too, that overeducation (which could be seen as under employment) is more prevalent than unemployment, the focus of the next section, affecting between 1.5 and 3 times as many individuals in this sample, depending upon how it is measured. The broad gender pattern for both measures is presented below: females have a lower incidence of overeducation than do males in the BHPS for both measures of overeducation, and the gender gap is larger under the second measure of overeducation. A partial explanation for this is that the categories used to create the second category become quite small, and this leads to no one being overeducated in 
some occupation-industry categories. For some categories, this is often especially so for females.

\section{[TABLE 2 ABOUT HERE]}

The breakdown by gender follows the overall categories with respect to the increasing incidence of overeducation over the duration of the dataset. This is as expected given the rising participation in higher education in the UK (see section 6.1).

The descriptive averages for life satisfaction for the overeducated do not indicate any significant difference from the life satisfaction for the whole of the population. Average self-reported life satisfaction of individuals, in their twenties, who are overeducated when measured by the first category (occupation only) is 5.22, and for the second category (occupation and industry) it is 5.16, whereas it is 5.21 for the lifecycle as a whole (recall that the scale is 1 to 7 , with 7 being completely satisfied with life). This latter figure includes, of course, the unemployed and their life satisfaction responses are, on average, 4.6 which brings the whole sample average down.

The happiness function used here is common to that of much of the 'economics of happiness' literature, but with the addition of a dummy variable for overeducation. Ultimately we decide to estimate using a dynamic specification (see below) hence the presence of the lagged dependent variable in the equation below.

$$
\begin{aligned}
& L S_{i t}=\alpha_{0}+\alpha_{0} L S_{i t-1}+\alpha 2 e d u c_{i t}+\alpha 3 \operatorname{lnwage}{ }_{i t}+\alpha_{4} \text { overed }_{i t}+X_{i}^{\prime} \beta+ \\
& \varepsilon_{i t} \quad \text { (1) }
\end{aligned}
$$


$L S_{i t}$ is the response of individual $i$ at time $t$ to the life satisfaction question, education which is captured by years of schooling of individual $i$ at time $t$, log wage which is based on labour income of individual $i$ at time $t$, and overeducation which is a dummy variable identifying whether or not individual $i$ is relatively overeducated at time $t . X_{i}$ is a k x 1 vector of covariates and $\beta$ is a $\mathrm{k} \mathrm{x} 1$ conformable vector of parameters, and $\varepsilon_{i t}$.is the standard random error term. We are especially interested in the overeducation coefficient, $\alpha_{4}$. If $\alpha_{4}$ is both negative and statistically significant, the estimate provides evidence for the hypothesis that being overeducated (relative to your peers) is associated with reduced life satisfaction (after income, education and other controls are taken into account).

The discussion now turns to the appropriate model choice. For the overeducation regressions the null of no first order correlation can be rejected $(p=0.0000)$, hence a discussion has to be had regarding the best way to model these omitted dynamics. The rest of the discussion of this section focuses on this. As Piper (2012) highlights, there are two main aspects that need to be considered with regards to the choice of model: is it statistically appropriate? Is the model informative regarding the investigation? ${ }^{2}$ The relative overeducation dummies are arguably contemporary variables with contemporaneous relevance (being currently overeducated is likely to impact on current life satisfaction) and can perhaps be assessed via a dynamic panel model. A note of caution is that the independent dummy variables will reflect only new

\footnotetext{
${ }^{2}$ Piper (2012) introduces dynamic panel analysis to the 'economics of happiness' area, discussing in detail the relevant issues and concerns, as well as providing decision rules regarding the appropriateness or otherwise of dynamic panel estimation. The initial motivation for such a method is due to the presence of serial correlation, representing omitted dynamics. As Piper (2012) demonstrates, even when serial correlation is present dynamic panel analysis is often, though not always, appropriate. See that study for more details, and the specific decision rules.
} 
information. If these dummies are 'quasi' fixed, then perhaps some of the information that is interesting would be captured in the 'black box' of the lagged dependent variable. The following table, 3, (extracted from Stata) shows the 'within an individual' variation, via the standard deviation measure, and demonstrates that individuals do move in and out of the overeducation categories. This indicates that there is enough variation in the dataset for useful analysis via fixed effects analysis or dynamic panel analysis. If the variation was negligible, then the modelling choice would be more limited. In the table the first measure of overeducation is based on occupation only; the second one is the advance which takes into consideration both occupation and industry. We are particularly interested in the standard deviation column (and to a lesser extent, the minimum and maximum columns), because these represent deviations from the individual's average. The figures in these columns demonstrate considerable 'within' person change. People do move into and out of overeducation enough for there to be enough variation for analysis.

\section{[TABLE 3 ABOUT HERE]}

Is dynamic panel modelling statistically appropriate? Some initial estimates were made to test this (output omitted, but discussed below in the results section) and the outcome is a qualified yes: in most variants the diagnostic tests are appropriate As the Piper (2012) highlighted, common factor restrictions need to be tested to see if the choice is a free one between modelling the dynamics in the observed part of the model or in the residual. The common factor restrictions here do hold. Further support for dynamic panel analysis is offered by the model passing Bond's informal test: the coefficient on the lagged dependent variable obtained via the dynamic model lies 
between the OLS and the fixed effects estimates (which are biased upwards and biased downwards respectively) (Bond 2002). Thus, dynamic panel modelling is statistically appropriate here.

Last, dynamic panel analysis seems, prima facie, more appropriate here because relative overeducation is a contemporary status: an individual is either overeducated now or not, and it is the impact on current life satisfaction that is of interest. Thus the independent dummy variable for overeducation is informative and so dynamic modelling is appropriate in terms of the likely information from the results. Thus the overeducation estimates will be modelled using the dynamic GMM procedures.

\section{Results}

This subsection collects the results of the overeducation estimates. In the previous section it was argued that a dynamic panel model is the preferred model because (a) it can address the omitted dynamics present in the data and (b) relative overeducation is a contemporary state so its effects are likely to be captured by the independent variable rather than being wholly captured by the lagged dependent variable itself. Lagged independent variables were used consistent with the non-rejection of the common factor restrictions, however they were all insignificant and so were dropped from the final models. The diagnostics regarding dynamic panel analysis, for these estimations, offer a free choice regarding instrumentation and lag length. The results presented here are from estimations that use 'default instrumentation', i.e. lags of t-2 and higher, but other instrumentation choices support the results obtained here. Minimum instrumentation gives qualitatively the same results in all cases. The overall 
result is that relative overeducation for employed individuals in the twenties age range is associated with lower life satisfaction, after controlling for education itself, income, and other standard controls. However, this is a result that requires qualification. A first inspection suggests that this finding is for males only. The happiness of females does not appear to be associated with overeducation at all. Table 4 presents the results from overeducation when measured by occupation only. With dynamic estimates, there are fewer observations than would be used by standard fixed effects analysis because the estimator requires consecutive lags of data. ${ }^{3}$ The columns represent all respondents, males only, and females only, respectively. In all cases, the standard errors are cluster robust to heteroscedasticity and arbitrary patterns of within-group correlation, and the estimation uses the twostep procedure.

\section{[TABLE 4 ABOUT HERE]}

The table provides the first evidence of a negative relationship between overeducation and life satisfaction. Other things being equal, the relatively overeducated are less satisfied than those who are not considered overeducated. This finding is statistically significant at the $1 \%$ level for everyone, and for males separately. Restricting the sample to females does not result in such an association: the sign on the overedcuation coefficient is negative but the p-value is approximately 0.23 and thus the estimated coefficient is not significant. For all the estimates in table 4, marriage, and excellent (and good) health are associated with higher life satisfaction; widowhood with lower. The coefficient on lagged life satisfaction, the lagged dependent variable, is highly statistically significant but very small. This finding is consistent with the results from

\footnotetext{
${ }^{3}$ The lack of the life satisfaction question in wave 11 of the BHPS is thus 'doubly' problematic for dynamic estimation.
} 
Piper (2012): past levels of life satisfaction have little to do with current life satisfaction. Happiness is very much a contemporary phenomenon. This small coefficient on the lagged dependent variable indicates that the long-run outcomes are not very different to the directly estimated coefficients of the model; long-run coefficients are calculated and included in the summary tables below.

The following table shows the long-run coefficient for relative overeducation. The long-run coefficient is calculated as in Wooldridge (2002). Given the low value of the lagged dependent variable, it is no surprise that the long run coefficients for overeducation are not too far from the short run (or contemporaneous) coefficients estimated above.

\section{[TABLE 5 ABOUT HERE]}

Regressions using the alternative measure of overeducation provide further support for individuals who are relatively overeducated reporting less satisfaction with life, other things being equal, and can be seen in table $6 .{ }^{4}$ When broken down into the genders such a conclusion is partially supported: there is no significant relationship at the 5 per cent level with life satisfaction for relatively overeducated males when estimated separately but there is at the $10 \%$ level; for females, when estimated separately, a negative relationship is supported at the $1 \%$ significance level. Following the table, further analysis splits the data set to investigate whether the negative effect of relative education on overeducation is consistent over time.

\section{[TABLE 6 ABOUT HERE]}

\footnotetext{
${ }^{4}$ The fewer waves that can be employed with this created reference group to measure overeducation (as explained above) explains the lower amount of observations used for the estimations when compared to the amount used in table 4.
} 
The results in table 6 , using the alternative measure of relative overeducation, does not fully support the conclusions drawn from the occupation-only measure. Here, both genders in the sample together maintain the negative relationship of overeducation for life satisfaction. The $\mathrm{p}$-value for overeducation for males only is 0.053 , a result that falls below the $5 \%$ level when the long run coefficient is calculated, as displayed in table 7 . With this alternative measure relative overeducation is negative for life satisfaction for females too.

\section{[TABLE 7 ABOUT HERE]}

The results presented in these tables seem to present strong evidence that overeducation is associated with lower life satisfaction. With both measures of overeducation used here, and for the whole sample, relative overeducation is negative and statistically significant at the $1 \%$ level with life satisfaction. Thus, the hypothesis of a negative relationship between these two variables is supported. Again, the longrun coefficients for overeducation are not too far from the short run (or contemporaneous) coefficients. This is similar to the results reported in Piper (2012), and is a reflection of the finding that happiness is largely a contemporary phenomenon. The results from the regressions that restrict the sample to each gender separately offer some support for this conclusion too, though at around the 5\% level rather than a $1 \%$ level.

An open question, given the increase in the participation of individuals regarding higher education (see section 6.1) is whether this finding is consistent over time. This particular analysis of the data suggests that there is a cohort effect: the negative impact of being relatively overeducated has an impact only in the earlier sample, and 
not the later sample. The two tables below present results from 1997-2000 (tables 8 and 9), and 2002-2007 (tables 10 and 11 respectively). This splits the dataset in two; remember that the life satisfaction question was not asked in wave 11,2011 , so this has been used as the break in the samples. The differences in the results for overeducation are striking and suggestions why this might be the case are provided after the tables.

\section{[TABLE 8 ABOUT HERE]}

Restricting the sample to $1997-2000$ indicates that the relatively overeducated are significantly less satisfied with life than those who are not overeducated. This is the case when the sample is restricted to males (at the 5\% significance level) but not when restricted to females. As overeducation here is measured by occupation only, this is consistent with the finding across the whole date range (table 4), As expected and as shown in table 9, given the coefficient on the lagged dependent variable (which reflects the history of the model), the long-run overeducation coefficients are similar to the independent variable coefficients for overeducation in table 8.

\section{[TABLE 9 ABOUT HERE]}

Restricting the sample to the later time period 2002-2007, as tables 10 and 11 show, indicate no statistically significant relationship between overeducation and life satisfaction, overall. This result is maintained when the sample is restricted to females, although the result for males demonstrates a significant negative relationship 
between these two variables. Being overeducated seems to matter less for satisfaction with life.

\section{[TABLE 10 ABOUT HERE]}

Again, the equivalent long-run coefficients are very similar. As table 11 shows, being relatively overeducated is not significantly associated with life satisfaction between 2002 and 2007, apart from the male only restriction.

\section{[TABLE 11 ABOUT HERE]}

This broad finding is supported with regressions making use of the alternative measure of overeducation: the results for 1997-2000 are very similar, with the negative relationship being significant at the 5\% level for both males and the whole sample (i.e. both genders), and statistically insignificant for females. For the later years, 2002-2007, the results for all three groups are insignificant, although the pvalue for the whole sample is 0.059 . These alternative results (output omitted) are slightly different from those presented above, but support the broad finding that the negative influence of overeducation on life satisfaction has faded over time. While we do not have a reason for this, we speculate that it is a function of increased participation in higher education, and changing expectations. With students appreciating that, as more individuals undertake higher education, a degree is not enough to get a good job (Adnett and Slack, 2007). Perhaps this result reflects a changing norm regarding what is a graduate job too. Also, with more individuals 
attending university there is perhaps less a cultural stigma to not being adequately rewarded in the labour market. More people, perhaps, know other people who have a degree but do not (as yet) have a graduate job. Thus the relatively overeducated are less unusual. This suggestion is similar to a finding in the unemployment and unhappiness literature, where being unemployed in a region with more unemployed people is less damaging to life satisfaction than being in a region with fewer unemployed individuals (Clark 2003). This speculation, if true, provides more support for life satisfaction having strong relative elements: which groups we compare ourselves with and how we compare to others matter for subjective well-being.

\section{Conclusion}

This section presented the first evidence of a negative association between relative overeducation and life satisfaction, and this was found via an appropriate econometric method (an important consideration often neglected in the economic literature). Serial correlation is present in the data, and this needs to be thoughtfully modelled. The method chosen needs to be appropriate, both statistically and economically and it must also be able to give informative results. Careful thought was given before deciding to model the overeducation-happiness relationship via dynamic panel methods and the results demonstrate that there is a negative impact of overeducation in terms of happiness. This result is robust to both the method of measuring relative overeducation, and the choice of instrumentation of the lagged dependent variable within the preferred dynamic panel method. This result adds to other results within the happiness literature that suggest that happiness is, often, based on relative concerns. Further analysis, however, suggests that this phenomenon is one that has faded with 
time, being more prevalent in the past when, we speculate, there may have been a greater stigma associated with education not being rewarded in the labour market. That there are more people who are considered overeducated, perhaps means that being relatively overeducated no longer makes people unhappy. Future research may analyse why and whether this is the case.

A criticism is, however, that the measures used in assessing overeducation are quite broad, but with a large dataset such as the BHPS there is no better alternative to capturing overeducation. The construction of the dummy variable by occupation (as in Groot 1996), and the improvement here by occupation combined with industry (creating 81 categories rather than 9) appear to be the best possible solutions. Alternative methods, not possible with the BHPS, involve subjective measures such as asking people about the skills required for their jobs seem beset with other problems (see the discussion above in section 2). The quality of education, or perceived quality, may well play a role given the conclusions of this section but there is no way for this to be assessed as yet.

Acknowledgements: For comments on earlier drafts, helpful discussions and advice the author is grateful to Nick Adnett, Andrew Clark and Geoff Pugh as well as seminar participants at Staffordshire University and Universität Flensburg. Thanks also to participants at the 2012 IWAEE event in Catanzaro, Italy, who also made valuable suggestions. The usual disclaimer applies.

\section{References}

Adnett, N. and Slack, K. (2007.) Are there economic incentives for non-traditional students to enter HE? The labour market as a barrier to widening participation. Higher Education Quarterly 61, 1: pp. 23-36. 
Alpin, C., Shackleton, J. and Walsh, S. (1998) Over- and Undereducation in the UK Graduate Labour Market, Studies in Higher Education 23, pp.17-34.

Battu, H., Belfield, C. and Sloane, P. (1999) Overeducation Among Graduates: A Cohort View, Education Economics 7, pp.21-38.

Belfield C. R. (2000) Economic Principles for Education: Theory and Evidence. Cheltenham: Edward Elgar.

Blázquez Cuesta, M. and Budría, S. (2012) Overeducation Dynamics and Personality, Education Economics 20, 3: pp. 260-283,

Boyce, C. J., Wood, A. M., \& Powdthavee, N. (2012) Is personality fixed? Personality changes as much as "variable" economic factors and more strongly predicts changes to life satisfaction. Social Indicators Research (in press).

Cassidy, T. and Wright, L. (2008) Graduate Employment Status and Health: a Longitudinal Analysis of the Transition from Student, Social Psychology of Education 11, pp. 181-191.

Clark, A. E., Frijters, P. and Shields, M. A. (2008) Relative Income, Happiness and Utility: An Explanation for the Easterlin Paradox and Other Puzzles, Journal of Economic Literature 46, 1: pp. 95-144.

Coburn, D. (1975) Job-Worker Incongruence: Consequences for Health, Journal of Health and Social Behavior 16, 2: pp. 198-212.

Dolton, P. and Vignoles, A. (1997) Overeducation Duration: How Long Did Graduates in the 1980s Take to Get a Graduate Level Job?, University of Newcastle, Unpublished mimeo.

Duesenberry, J. S. (1949) Income, Savings, and the Theory of Consumer Behaviour. Cambridge: Harvard University Press.

Fleming C. M. and Kler P. (2007) I'm Too Clever for this Job: A Bivariate Probit Analysis on Overeducation and Job Satisfaction in Australia, Applied Economics 40, 9: pp. 1123-1138.

Frank, R. H. (1985) Choosing the Right Pond. Human Behaviour and the Quest for Status. New York: Oxford University Press.

Groot, W. (1993) Overeducation and the Returns to Enterprise-related Schooling, Economics of Education Review 12, pp. 299-309.

Groot, W. (1996), The Incidence of, and Returns to Overeducation in the UK, Applied Economics, 28, pp. 1345-1350.

Groot, W. and Massen van den Brink, H. (2000) Overeducation in the Labor 
Market: a Meta Analysis, Economics of Education Review 19, pp. 149-158.

Kasl, S. (1974) Work and mental health, in Work and the Quality of Life edited by O’Toole, J. pp.171-196. Cambridge, MA: MIT Press.

Khattab, N. and Fenton, S. (2009) What Makes Young Adults Happy? Employment and Non-work as Determinants of Life Satisfaction, Sociology 43, 1: pp. 11-26.

Kiker, B. F., Santos, M. C. and De Oliveira, M. M. (1997) Overeducation and Undereducation: Evidence for Portugal. Economics of Education Review 16, pp. 111125 .

Kucel, A. (2011) Literature Survey of the Incidence of Over-education: A Sociological Approach, Revista Española de Investigaciones Sociologicas 134, p.125142.

Leuven, E. and Oosterbeek, H. (2011) Overeducation and mismatch in the labor market in Hanushek, E. A., Machin, S. and Woessmann, L (ed.), Handbook of The Economics of Education, Volume 4. Cambridge: Elsevier. pp. 283 - 326.

Piper, A. T. (2012) Life Satisfaction and Dynamic Panel Analysis: Discussion, Decision Rules, and

Rubb, S. (2003) Overeducation in the Labor Market: A Comment and Re-Analysis of a Meta-Analysis, Economics of Education Review 22, 6: pp. 621-629.

Sicherman, N. (1991) Overeducation in the Labour Market, Journal of Labor Economics 9, 2: pp. 101-122.

Sloane, P., Battu, H., and Seaman, P. (1999) Overeducation, Undereducation and the British Labour Market, Applied Economics 31,pp.1437-1453.

Verdugo, R. and Verdugo, N. T. (1989). The impact of surplus schooling on earnings: Some additional findings. Journal of Human Resources 24, pp. 629-643.

Verhaest, D. and Omey, M. (2006) The Impact of Overeducation and its Measurement, Social Indicators Research 77, 3: pp. 419-448.

Wooldridge, J. M. (2002) Econometric Analysis of Cross Section and Panel Data. Cambridge, MA: MIT Press. 
Table 1 Incidence of overeducation in the BHPS, selected waves

\begin{tabular}{|c|c|c|}
\hline & Occupation only (1) & Occupation and industry (2) \\
\hline Wave & Percent overeducated & Percent overeducated \\
\hline $1(1991)$ & 9.9 & 6.5 \\
\hline $8(1998)$ & 19.7 & 14.0 \\
\hline $15(2005)$ & 20.5 & 14.5 \\
\hline Overall & (waves 1-15) 18.0 & 13.9 \\
\hline
\end{tabular}

Table 2 Incidence of overeducation by gender.

Occupation only (1)

Percent overeducated

All

Males

Females
18.2

19.5

17.0
Occupation and industry (2)

Percent overeducated

10.7

12.9

8.9

(Source: own calculations based on BHPS data 1991-2008)

Table 3 Variation of overeducation dummy variables, BHPS 1991-2008

\begin{tabular}{|c|c|c|c|c|c|}
\hline Variable & Mean & Std. Dev. & Min & Max & Observations \\
\hline overe & 0.182 & 0.228 & -0.727 & 1.091 & bar $=3.7$ \\
\hline overeducation (2) & 0.108 & 0.207 & -0.801 & $1.017 \mid$ & $\Gamma-$ bar $=3.7$ \\
\hline
\end{tabular}


Table 4 Life satisfaction and overeducation (measured by occupation), System GMM panel analysis, BHPS.

\begin{tabular}{|c|c|c|c|}
\hline VARIABLES & $\begin{array}{c}\text { All } \\
\text { Life Satisfaction }\end{array}$ & $\begin{array}{c}\text { Males only } \\
\text { Life Satisfaction }\end{array}$ & $\begin{array}{c}\text { Females only } \\
\text { Life Satisfaction }\end{array}$ \\
\hline Life satisfaction (t-1) & $\begin{array}{l}0.06^{* * *} \\
(0.022)\end{array}$ & $\begin{array}{l}0.07^{* *} \\
(0.026)\end{array}$ & $\begin{array}{c}0.05^{*} \\
(0.032)\end{array}$ \\
\hline Years of Schooling & $\begin{array}{l}0.02^{* *} \\
(0.008)\end{array}$ & $\begin{array}{c}0.01 \\
(0.011)\end{array}$ & $\begin{array}{c}0.02 \\
(0.012)\end{array}$ \\
\hline Income & $\begin{array}{l}-0.09^{*} \\
(0.053)\end{array}$ & $\begin{array}{c}0.06 \\
(0.081)\end{array}$ & $\begin{array}{l}-0.07 \\
(0.072)\end{array}$ \\
\hline Overeducated & $\begin{array}{l}-0.11^{* \star *} \\
(0.034)\end{array}$ & $\begin{array}{l}-0.13^{* \star \star} \\
(0.047)\end{array}$ & $\begin{array}{l}-0.06 \\
(0.049)\end{array}$ \\
\hline Married & $\begin{array}{l}0.37^{\star * *} \\
(0.073)\end{array}$ & $\begin{array}{l}0.33^{* * *} \\
(0.092)\end{array}$ & $\begin{array}{l}0.28^{* * *} \\
(0.106)\end{array}$ \\
\hline Separated & $\begin{array}{c}0.22 \\
(0.423)\end{array}$ & $\begin{array}{l}-0.70 \\
(0.645)\end{array}$ & $\begin{array}{c}0.41 \\
(0.316)\end{array}$ \\
\hline Divorced & $\begin{array}{c}0.29 \\
(0.248)\end{array}$ & $\begin{array}{c}0.03 \\
(0.315)\end{array}$ & $\begin{array}{c}0.07 \\
(0.230)\end{array}$ \\
\hline Widowed & $\begin{array}{l}-2.24^{* * *} \\
(0.713)\end{array}$ & & $\begin{array}{l}-1.95^{\star \star *} \\
(0.494)\end{array}$ \\
\hline Health: excellent & $\begin{array}{l}0.77^{* * *} \\
(0.171)\end{array}$ & $\begin{array}{l}0.47^{* * *} \\
(0.172)\end{array}$ & $\begin{array}{l}1.12^{* * *} \\
(0.211)\end{array}$ \\
\hline Health: good & $\begin{array}{l}0.33^{* *} \\
(0.155)\end{array}$ & $\begin{array}{l}0.33^{* *} \\
(0.144)\end{array}$ & $\begin{array}{l}0.60^{* * *} \\
(0.184)\end{array}$ \\
\hline Age $20-22$ & $\begin{array}{c}0.05 \\
(0.049)\end{array}$ & $\begin{array}{l}0.11^{*} \\
(0.066)\end{array}$ & $\begin{array}{c}-0.01 \\
(0.066)\end{array}$ \\
\hline Age 23-24 & $\begin{array}{c}0.04 \\
(0.039)\end{array}$ & $\begin{array}{c}0.02 \\
(0.052)\end{array}$ & $\begin{array}{c}0.05 \\
(0.054)\end{array}$ \\
\hline Age $25-26$ & $\begin{array}{c}0.04 \\
(0.031)\end{array}$ & $\begin{array}{c}0.04 \\
(0.043)\end{array}$ & $\begin{array}{c}0.02 \\
(0.043)\end{array}$ \\
\hline Wave dummies? & Yes & Yes & Yes \\
\hline Region dummies? & Yes & Yes & Yes \\
\hline Constant & $\begin{array}{l}4.87^{* * *} \\
(0.399)\end{array}$ & $\begin{array}{l}3.87^{* * *} \\
(0.641)\end{array}$ & $\begin{array}{l}4.64^{* * *} \\
(0.563)\end{array}$ \\
\hline Observations & 9,839 & 4,796 & 5,043 \\
\hline Number of individuals & 3,868 & 1,864 & 2,004 \\
\hline Number of instruments & 415 & 367 & 402 \\
\hline
\end{tabular}

Standard errors in parentheses

${ }^{* * *} p<0.01,{ }^{* *} p<0.05,{ }^{*} p<0.1$ 
Table 5 Long run overeducation coefficients calculated from table 4

\begin{tabular}{|l|l|l|l|}
\hline & All & Male & Female \\
\hline $\begin{array}{l}\text { Long-run } \\
\text { overeducation } \\
\text { coefficient }\end{array}$ & $-0.122 * * *$ & $-0.140 * * *$ & -0.063 \\
$(\mathrm{p}=0.001)$ & $(\mathrm{p}=0.005)$ & $(\mathrm{p}=0.228)$ \\
\hline
\end{tabular}


Table 6 Life satisfaction and overeducation (measured by occupation and industry), System GMM panel analysis, BHPS.

\begin{tabular}{|c|c|c|c|}
\hline VARIABLES & $\begin{array}{c}\text { All } \\
\text { Life Satisfaction }\end{array}$ & $\begin{array}{c}\text { Males only } \\
\text { Life Satisfaction }\end{array}$ & $\begin{array}{c}\text { Females only } \\
\text { Life Satisfaction }\end{array}$ \\
\hline Life satisfaction (t-1) & $\begin{array}{l}0.09^{* * *} \\
(0.030)\end{array}$ & $\begin{array}{c}0.05 \\
(0.041)\end{array}$ & $\begin{array}{l}0.13^{* * *} \\
(0.043)\end{array}$ \\
\hline Years of Schooling & $\begin{array}{l}0.04^{* * *} \\
(0.014)\end{array}$ & $\begin{array}{c}0.01 \\
(0.018)\end{array}$ & $\begin{array}{l}0.05^{\star *} \\
(0.022)\end{array}$ \\
\hline Income & $\begin{array}{c}-0.13 \\
(0.105)\end{array}$ & $\begin{array}{c}0.06 \\
(0.147)\end{array}$ & $\begin{array}{l}-0.26^{*} \\
(0.157)\end{array}$ \\
\hline Overeducated & $\begin{array}{l}-0.25^{* * *} \\
(0.074)\end{array}$ & $\begin{array}{l}-0.21^{*} \\
(0.108)\end{array}$ & $\begin{array}{l}-0.23^{* *} \\
(0.116)\end{array}$ \\
\hline Married & $\begin{array}{l}0.35^{* * *} \\
(0.102)\end{array}$ & $\begin{array}{c}0.23^{*} \\
(0.127)\end{array}$ & $\begin{array}{l}0.45^{* * *} \\
(0.145)\end{array}$ \\
\hline Separated & $\begin{array}{c}-0.01 \\
(0.588)\end{array}$ & $\begin{array}{c}0.19 \\
(1.196)\end{array}$ & $\begin{array}{c}0.23 \\
(0.365)\end{array}$ \\
\hline Divorced & $\begin{array}{c}0.31 \\
(0.252)\end{array}$ & $\begin{array}{c}0.21 \\
(0.375)\end{array}$ & $\begin{array}{c}0.13 \\
(0.244)\end{array}$ \\
\hline Widowed & Dropped & Dropped & Dropped \\
\hline Health: excellent & $\begin{array}{l}0.87^{* * *} \\
(0.203)\end{array}$ & $\begin{array}{l}0.48^{* *} \\
(0.239)\end{array}$ & $\begin{array}{l}1.07^{* * *} \\
(0.260)\end{array}$ \\
\hline Health: good & $\begin{array}{l}0.45^{\star *} \\
(0.179)\end{array}$ & $\begin{array}{c}0.21 \\
(0.216)\end{array}$ & $\begin{array}{l}0.65^{* * *} \\
(0.200)\end{array}$ \\
\hline Age $20-22$ & $\begin{array}{c}0.06 \\
(0.066)\end{array}$ & $\begin{array}{c}0.11 \\
(0.085)\end{array}$ & $\begin{array}{l}-0.01 \\
(0.085)\end{array}$ \\
\hline Age 23-24 & $\begin{array}{c}0.05 \\
(0.053)\end{array}$ & $\begin{array}{c}0.02 \\
(0.075)\end{array}$ & $\begin{array}{c}0.07 \\
(0.073)\end{array}$ \\
\hline Age $25-26$ & $\begin{array}{c}0.06 \\
(0.040)\end{array}$ & $\begin{array}{c}0.06 \\
(0.057)\end{array}$ & $\begin{array}{c}0.00 \\
(0.055)\end{array}$ \\
\hline Wave dummies? & Yes & Yes & Yes \\
\hline Region dummies? & Yes & Yes & Yes \\
\hline Constant & $\begin{array}{l}4.58^{* * *} \\
(0.677)\end{array}$ & $\begin{array}{l}3.89^{* * *} \\
(1.116)\end{array}$ & $\begin{array}{l}4.91^{* * *} \\
(0.938)\end{array}$ \\
\hline Observations & 5,898 & 3,170 & 2,728 \\
\hline Number of individuals & 2,643 & 1,373 & 1,270 \\
\hline Number of instruments & 288 & 268 & 271 \\
\hline
\end{tabular}

Standard errors in parentheses

${ }^{* * *} p<0.01,{ }^{* *} p<0.05,{ }^{*} p<0.1$ 
Table 7 Long run overeducation coefficients calculated from table 7.6

\begin{tabular}{|l|l|l|l|}
\hline & All & Male & Female \\
\hline $\begin{array}{l}\text { Long-run } \\
\text { overeducation } \\
\text { coefficient }\end{array}$ & $-0.269^{* * *}$ & $-0.220^{* *}$ & $-0.266^{* *}$ \\
$(\mathrm{p}=0.001)$ & $(\mathrm{p}=0.048)$ & $(\mathrm{p}=0.046)$ \\
\hline
\end{tabular}


Table 7.8 Life satisfaction and overeducation (measured by occupation), System GMM panel analysis, BHPS 1997-2000

\begin{tabular}{|c|c|c|c|}
\hline VARIABLES & $\begin{array}{c}\text { All } \\
\text { Life } \\
\text { Satisfaction }\end{array}$ & $\begin{array}{l}\text { Males only } \\
\quad \text { Life } \\
\text { Satisfaction }\end{array}$ & $\begin{array}{l}\text { Females only } \\
\text { Life } \\
\text { Satisfaction }\end{array}$ \\
\hline Life satisfaction (t-1) & $\begin{array}{c}0.07^{* *} \\
(0.036)\end{array}$ & $\begin{array}{c}0.08 \\
(0.053)\end{array}$ & $\begin{array}{c}0.10^{*} \\
(0.053)\end{array}$ \\
\hline Years of Schooling & $\begin{array}{c}0.01 \\
(0.013)\end{array}$ & $\begin{array}{c}0.00 \\
(0.016)\end{array}$ & $\begin{array}{c}0.01 \\
(0.019)\end{array}$ \\
\hline Income & $\begin{array}{c}-0.15 \\
(0.099)\end{array}$ & $\begin{array}{c}-0.02 \\
(0.164)\end{array}$ & $\begin{array}{c}-0.08 \\
(0.122)\end{array}$ \\
\hline Overeducated & $\begin{array}{l}-0.14^{* *} \\
(0.057)\end{array}$ & $\begin{array}{l}-0.17^{* *} \\
(0.075)\end{array}$ & $\begin{array}{c}-0.08 \\
(0.088)\end{array}$ \\
\hline Married & $\begin{array}{l}0.49^{* * *} \\
(0.113)\end{array}$ & $\begin{array}{l}0.38^{\star \star \star} \\
(0.146)\end{array}$ & $\begin{array}{l}0.42^{\star *} \\
(0.185)\end{array}$ \\
\hline Separated & $\begin{array}{c}0.09 \\
(0.722)\end{array}$ & $\begin{array}{c}-0.75 \\
(0.639)\end{array}$ & $\begin{array}{c}0.72 \\
(0.678)\end{array}$ \\
\hline Divorced & $\begin{array}{c}0.42 \\
(0.336)\end{array}$ & $\begin{array}{c}0.30 \\
(0.549)\end{array}$ & $\begin{array}{c}0.28 \\
(0.353)\end{array}$ \\
\hline Widowed & $\begin{array}{c}-3.71 \\
(7.765)\end{array}$ & & $\begin{array}{c}-5.13 \\
(4.986)\end{array}$ \\
\hline Health: excellent & $\begin{array}{l}0.75^{\star * *} \\
(0.277)\end{array}$ & $\begin{array}{c}0.39 \\
(0.309)\end{array}$ & $\begin{array}{l}1.26^{\star * *} \\
(0.303)\end{array}$ \\
\hline Health: good & $\begin{array}{c}0.16 \\
(0.220)\end{array}$ & $\begin{array}{c}-0.01 \\
(0.309)\end{array}$ & $\begin{array}{c}0.59^{* *} \\
(0.243)\end{array}$ \\
\hline Age $20-22$ & $\begin{array}{c}0.17^{\star *} \\
(0.078)\end{array}$ & $\begin{array}{c}0.15 \\
(0.105)\end{array}$ & $\begin{array}{c}0.14 \\
(0.119)\end{array}$ \\
\hline Age $23-24$ & $\begin{array}{c}0.13^{* *} \\
(0.062)\end{array}$ & $\begin{array}{c}0.04 \\
(0.085)\end{array}$ & $\begin{array}{c}0.19^{*} \\
(0.100)\end{array}$ \\
\hline Age $25-26$ & $\begin{array}{l}0.12^{\star \star \star} \\
(0.047)\end{array}$ & $\begin{array}{c}0.10 \\
(0.064)\end{array}$ & $\begin{array}{c}0.15^{*} \\
(0.080)\end{array}$ \\
\hline Wave dummies? & Yes & Yes & Yes \\
\hline Region dummies? & Yes & Yes & Yes \\
\hline Constant & $\begin{array}{l}5.31^{* \star *} \\
(0.736)\end{array}$ & $\begin{array}{l}4.64^{* \star *} \\
(1.272)\end{array}$ & $\begin{array}{l}4.38^{* * *} \\
(0.912)\end{array}$ \\
\hline Observations & 4,305 & 2,189 & 2,116 \\
\hline Number of individuals & 2,086 & 1,038 & 1,048 \\
\hline Number of instruments & 178 & 162 & 172 \\
\hline
\end{tabular}


Table 9 Long-run overeducation coefficients calculated from table 8

\begin{tabular}{|l|l|l|l|}
\hline & All & Male & Female \\
\hline $\begin{array}{l}\text { Long-run } \\
\text { overeducation } \\
\text { coefficient }\end{array}$ & $-0.146^{* *}$ & $-0.181^{* *}$ & -0.092 \\
$(\mathrm{p}=0.016)$ & $(\mathrm{p}=0.018)$ & $(\mathrm{p}=0.344)$ \\
\hline
\end{tabular}


Table 10 Life satisfaction and overeducation (measured by occupation), System GMM panel analysis, BHPS 2002-2007

\begin{tabular}{|c|c|c|c|}
\hline & $\begin{array}{c}\text { All } \\
\text { Life }\end{array}$ & Males only & Females only \\
\hline VARIABLES & Satisfaction & Life Satisfaction & Life Satisfaction \\
\hline \multirow[t]{2}{*}{ Life satisfaction (t-1) } & $0.05^{\star}$ & 0.05 & 0.01 \\
\hline & $(0.027)$ & $(0.032)$ & $(0.034)$ \\
\hline \multirow[t]{2}{*}{ Years of Schooling } & $0.02^{* *}$ & 0.02 & 0.02 \\
\hline & $(0.011)$ & $(0.014)$ & $(0.016)$ \\
\hline \multirow[t]{2}{*}{ Income } & -0.05 & 0.05 & -0.08 \\
\hline & $(0.090)$ & $(0.085)$ & $(0.087)$ \\
\hline \multirow[t]{2}{*}{ Overeducated } & -0.06 & $-0.14^{\star *}$ & -0.01 \\
\hline & $(0.043)$ & $(0.060)$ & $(0.059)$ \\
\hline \multirow[t]{2}{*}{ Married } & $0.28^{* * *}$ & $0.30^{\star *}$ & $0.27^{* *}$ \\
\hline & $(0.095)$ & $(0.127)$ & $(0.134)$ \\
\hline \multirow[t]{2}{*}{ Separated } & 0.37 & -0.16 & 0.19 \\
\hline & $(0.436)$ & $(1.261)$ & $(0.255)$ \\
\hline \multirow[t]{2}{*}{ Divorced } & 0.17 & -0.41 & -0.01 \\
\hline & $(0.347)$ & $(0.897)$ & $(0.340)$ \\
\hline \multirow[t]{2}{*}{ Widowed } & $-2.18^{\star \star \star}$ & & $-2.21^{* * *}$ \\
\hline & $(0.661)$ & & $(0.670)$ \\
\hline \multirow[t]{2}{*}{ Health: excellent } & $0.83^{* * *}$ & $0.47^{* *}$ & $0.99^{* * *}$ \\
\hline & $(0.204)$ & $(0.204)$ & $(0.269)$ \\
\hline \multirow[t]{2}{*}{ Health: good } & $0.48^{* * *}$ & $0.45^{* *}$ & $0.50^{* *}$ \\
\hline & $(0.183)$ & $(0.193)$ & $(0.239)$ \\
\hline \multirow[t]{2}{*}{ Age $20-22$} & -0.02 & 0.05 & -0.11 \\
\hline & $(0.068)$ & $(0.084)$ & $(0.080)$ \\
\hline \multirow[t]{2}{*}{ Age $23-24$} & -0.02 & -0.02 & -0.04 \\
\hline & $(0.051)$ & $(0.067)$ & $(0.065)$ \\
\hline \multirow[t]{2}{*}{ Age $25-26$} & -0.03 & -0.02 & -0.06 \\
\hline & $(0.042)$ & $(0.059)$ & $(0.054)$ \\
\hline Wave dummies? & Yes & Yes & Yes \\
\hline Region dummies? & Yes & Yes & Yes \\
\hline Constant & $4.51^{* * *}$ & $3.91^{* * *}$ & $4.94^{* * *}$ \\
\hline & $(0.622)$ & $(0.675)$ & $(0.639)$ \\
\hline Observations & 5,534 & 2,607 & 2,927 \\
\hline Number of individuals & 2,340 & 1,095 & 1,245 \\
\hline Number of instruments & 260 & 228 & 253 \\
\hline
\end{tabular}


Table 11 Long-run overeducation coefficients calculated from table 10

\begin{tabular}{|l|l|l|l|}
\hline & All & Male & Female \\
\hline $\begin{array}{l}\text { Long-run } \\
\text { overeducation } \\
\text { coefficient }\end{array}$ & -0.066 & $-0.142^{* *}$ & -0.008 \\
$(\mathrm{p}=0.138)$ & $(\mathrm{p}=0.024)$ & $(\mathrm{p}=0.889)$ \\
\hline
\end{tabular}

